\title{
PENGARUH KUALITAS PELAYANAN DAN KEPERCAYAAN TERHADAP KEPUASAN PASIEN BPJS \\ DI KLINIK ISNA MEDIKA KOTA CILEGON
}

\author{
Khairul Ikhsan $^{1}$, Anggit Yoebrilianti ${ }^{2}$, Nurhasanah ${ }^{3}$ \\ Fakultas Ekonomi dan Bisnis Universitas Serang Raya, Serang. \\ khairulikhsan@unsera.ac.id1, anggitbriliant@gmail.com2 \\ Nhasanah967@gmail.com3
}

\begin{abstract}
ABSTRAK
Kualitas Pelayanan dan kepercayaan mempunyai peran yang sangat penting terhadap kepuasan pelanggan. Perusahaan di bidang jasa harus mengutamakan kualitas pelayananannya, bukan hanya untuk kepentingan perusahaan melainkan juga kepentingan bagi pihak konsumen agar mendapatkan rasa puas. Kualitas pelayanan yang diberikan oleh perusahaan merupakan kinerja terpenting perusahaan bagi kepuasan pelanggan. Klinik Isna Medika harus memperhatikan hal-hal penting bagi pelanggan, agar pelanggan mempunyai rasa percaya dan puas sebagaimana yang dirasakan. Tujuan penelitian ini untuk mengetahui dan menguji pengaruh Kualitas Pelayanan dan Kepercayaan Terhadap Kepuasan pasien BPJS Klinik Isna Medika di Kota Cilegon. Penelitian ini menggunakan sampel sebanyak 120 responden dari BPJS Klinik Isna Medika di Kota Cilegon. Hasil penelitian ini menunjukkan bahwa kualitas pelayanan berpengaruh positif dan signifikan terhadap kepuasan pelanggan, sedangkan kepercayaan tidak.
\end{abstract}

Kata Kunci: Kualitas pelayanan, Kepercayaan, dan Kepuasan pelanggan

\section{ABSTRACT}

Service quality and trust have a very important role on customer satisfaction. Company in the service sector must prioritize their service quality, not only for the company's benefit but also for the consumers satisfaction. The service quality is provided by the company is the most important performance for company to satisfy customer. Isna Medika Clinic must pay attention to important things for customers, so that customers feel a trust and satisfaction toward the organization. The purpose of this study was to determine and test the effect of Service Quality and Trust on BPJS's Patient Satisfaction in using health service in Isna Medika Clinic in Cilegon City. This study used 120 respondents as a research sampel from BPJS's Patient in Isna Medika Clinic in Cilegon City. The results of this study exhibit that service quality has a positive and significant effect on customer satisfaction, while trust is not.

Keywords : Service Quality, Trust, Cutomer Satisfaction. 


\section{PENDAHULUAN}

Kualitas pelayanan merupakan titik sentral bagi perusahaan jasa karena akan mempengaruhi kepuasan pelanggan, pelanggan akan merasa puas apabila mereka mendapatkan pelayanan dengan kualitas terbaik. Perusahaan dapat memenangkan persaingan ketika meraka mampu menciptakan nilai dan memberi kepuasan kepada pelanggan dengan memberikan produk dan layanan yang berkualitas. Hal ini dikarenakan kualitas pelayanan yang baik akan mampu menciptakan kepuasan bagi konsumennya. Apabila konsumen merasa puas mereka akan terus menggunakan jasa yang diberikan perusahaan dan memberikan rekomendasi kepada orang lain untuk ikut menggunakan jasa yang sama. Selain itu, kepercayaan pelanggan terhadap perusahaan juga dapat mempengaruhi tingkat kepuasan pelanggan tersebut karena konsumen hanya akan merasa puas jika mereka merasa perusahaan memberikan produk atau layanan yang berkualitas, konsisten, jujur dan bertanggung jawab. Dengan begitu, pelanggan yang merasa puasa terhadap produk atau layanan yang diberikan perusahaan mereka akan memberikan manfaat bagi perusahaan yaitu harmonisnya hubungan antara perusahaan dan pelanggannya.

Klinik sebagai salah satu fasilitas pelayanan kesehatan mempunyai peranan penting dalam mencapai tujuan kesehatan yang diharapkan dapat memberikan pelayanan yang efisien, efektif, dan dituntut untuk memberikan informasi kesehatan yang tepat dan menghasilkan data yang akurat dalam pelayanan kesehatan. Klinik Isna Medika merupakan salah satu klinik penyedia layanan kesehatan yang berada di J1. Raya Merak Km. 8 Link. Keserangan Desa Rawa Arum, Grogol, Kota Cilegon Banten. Klinik ini menyediakan jasa pelayanan selama 24 jam bagi setiap pasien yang datang ketika berobat, bukan hanya melayani berobat biasa, Klinik ini juga melayani kesehatan ibu hamil dalam melakukan proses melahirkan dan melayani kesehatan gigi. Klinik Isna Medika harus memberikan kualitas pelayanan dan kepercayaan yang bisa memberikan kepuasan bagi masyarakat khususnya pasien BPJS dalam memberikan pandangan baik bahwa konsumen merasa puas memakai kualitas pelayanan dan percaya pada Klinik Isna Medika. Berikut jumlah pasien BPJS di Klinik Isna Medika Cabang Cilegon selama tahun 2017 dan 2018.

Tabel 1.

\section{Jumlah pasien BPJS di Klinik Isna Medika}

\begin{tabular}{lcc}
\hline \multirow{2}{*}{ Bulan } & \multicolumn{2}{c}{ Jumlah Pasien BPJS } \\
\cline { 2 - 3 } & 2017 & 2018 \\
\hline Januari & 59 & 67 \\
Februari & 41 & 28 \\
Maret & 38 & 54 \\
April & 47 & 62 \\
Mei & 32 & 37 \\
Juni & 28 & 51 \\
Juli & 35 & 39 \\
Agustus & 66 & 44 \\
September & 52 & 60 \\
Oktober & 34 & 57 \\
November & 31 & 38 \\
Desember & 47 & 47 \\
\hline Jumlah & 510 & 581 \\
\hline
\end{tabular}


Berdasarkan Tabel 1.1 jumlah pasien BPJS di Klinik Isna Medika Cabang Cilegon pada tahun 2017 dan 2018 berfluktuasi setiap bulannya. Jumlahnya mengalami kenaikan dan penurunan yang tidak stabil. Kualitas pelayanan dalam hal kepedulian terhadap pasien BPJS yang berobat tidak berbeda dengan pasien lain. Mereka tetap dilayani meskipun belum memiliki biaya ataupun surat keterangan miskin. Ada beberapa kemungkinan yang menyebabkan jumlah pasien berfluktuatif dan tidak stabil, antara lain karena kualitas pelayanan yang diberikan kurang memuaskan, seperti fasilitas yang kurang memadai, dan lambatnya penanganan medis terhadap pasien yang menimbulkan komplain dan kritikan dari pasien yang pernah memakai jasa pelayanan di Klinik Isna Medika cabang Cilegon. Bukan hanya itu, kemungkinan berkurangnya kepercayaan pasien terhadap kinerja dokter dan perawat akibat kurangnya kualitas pelayanan yang diberikan juga bisa menyebabkan kurang puasnya pasien BPJS di Klinik Isna Medika. Oleh karena itu, penelitian ini bertujuan untuk mengetahui dan menguji pengaruh kualitas pelayanan dan kepercayaan terhadap kepuasan peserta BPJS pada Klinik Isna Medika di Kota Cilegon.

\section{KAJIAN PUSATAKA \\ Kualitas Pelayanan}

Tjiptono dan Chandra (2012) mendefinisikan kualitas pelayanan sebagai ukuran seberapa bagus tingkat layanan yang diberikan mampu sesuai dengan ekspektasi pelanggan. Setiawan (2016) mengklaim bahwa kualitas pelayanan mengacu pada harapan konsumen berdasarkan pengalam dan reputasi suatu perusahaan. Hal ini disebabkan oleh pandangan konsumen yang selalu mempertimbangkan sejauh mana nilai dari uang yang dikeluarkan dalam memutuskan apakah akan kembali menggunakan layanan tersebut atau tidak (Park et al., dalam Setiawan, 2016). Artinya, kualitas pelayanan menekankan peran layanan yang diberikan harus memiliki kualitas yang baik dari setiap aspek yang ada mulai dari produk, jasa, manusia, proses, dan lingkungan agar dapat memenuhi keinginan dan ekspektasi konsumen. Dengan begitu, persepsi konsumen terhadap tinggi rendanya tingkat pelayanan yang diberikan akan mencerminkan kualitas pelayanan itu sendiri (Tanudjaya, 2014). Menurut Parasuraman et al., (dalam Tjiptono dan Chandra, 2012) mengungkapkan terdapat lima indikator atau penentu kualitas pelayanan jasa, yaitu:

1. Bukti Fisik (Tangibles), berkenan dengan penampilan fisik, peralatan, personil dan materi komunikasi.

2. Kehandalan (Reability), berkaitan dengan kemampuan kemampuan perusahaan untuk memberikan jasa yang tepat tanpa membuat kesalahan apapun dan menyampaikan jasanya sesuai dengan waktu yang disepakati.

3. Daya Tanggap (Responsiveness), berkenan dengan kesediaan dan kemampuan para karyawan untuk membantu para pelanggan dan merespon permintaan mereka, serta menginformasikan kapan jasa akan diberikan.

4. Jaminan/kepastian (Assurance), 
perilaku karyawan mampu menimbulkan kepercayaan pelanggan terhadap perusahaan dan perusahaan bias menciptakan rasa aman bagi para pelanggannya.

5. Empati (Empathy) bahwa perusahaan memahami masalah para pelanggannyadan bertindak demi kepentingan pelanggan, serta memberikan perhatian personal kepada para pelanggan.

\section{Kepercayaan}

Kepercayaan

merupakan

kesediaan atau kerelaan untuk bersandar pada rekan yang terlibat dan pertukaran yang diyakini (Ball et al., 2016). Pendapat tersebut didukung oleh pandangan Kotler dan Keller(2012) yang mengatakan bahwa kepercayaan adalah kesediaan perusahaan untuk bergantung pada mitra bisnis. Kepercayaan sangat bergantung pada beberapa faktor antar pribadi dan antar organisasi seperti kompetensi, integritas, kejujuran dan kebaikan hati. Hal ini menandakan bahwa ketika seseorang atau perusahaan memiliki integritas dan kejujusan mereka akan dipercaya oleh pihak lain yaitu konsumen. Menurut Mayer et al. (dalam Thomas, 2017:23) menyatakan terdapat tiga indikator yang membentuk kepercayaan, yaitu:

1. Kemampuan (Ability)

Kemampuan berkaitan dengan kompetensi dan karakteristik dari para pelaku dalam memberikan layanan kepada konsumen, dalam hal ini konsumen perlu mendapat jaminan kepuasan dan keamanan daripada penyedia jasa dalam melakukan transaksi. Bagian dari kemampuan ini adalah: kompetensi, pengalaman, kemampuan dalam ilmu pengetahuan.

2. Integritas (Integrity)

Komitmen perilaku penyedia jasa untuk menjalankan aktifitas bisnis yang benar-benar sesuai janji yang telah disampaikan kepada konsumen, sehingga hal ini menjadi salah satu penentu perusahaan ini dapat dipercaya atau tidak oleh konsumen.

3. Kebaikan Hati (Benevolence)

Penyedia jasa untuk mampu memberikan kepuasan kepada konsumen. Perusahaan tidak hanya sekedar mengejar maksimalisasi profit melainkan juga harus memperhatikan kepuasan konsumen, aspek-aspek benevolence meliputi empati, keyakinan, dan daya terima.

\section{Kepuasan Pelanggan}

Kotler dan Keller (2012) mengatakan bahwa kepuasan merupakan tingkat keadaan perasaan seseorang setelah membandingkan kinerja suatu produk yang dirasakan dengan harapannya. Lebih jauh, kepuasan merupakan bentuk reaksi emosional terhadap pengalaman atas suatu produk atau jasa yang didasarkan oleh informasi yang digunakan untuk memiliki suatu produk (Wijayanti 2008). Oleh karena itu, perusahaan harus mampu memperhatikan setiap berbagai macam aspek yang dapat membentuk kepuasan konsumen. Menurut Kotler (dalam Suwardi, 2011) terdapat beberapa indikator yang dapat menggambarkan kepuasan pelanggan yaitu:

1. Re-Purchase: membeli kembali, 
dimana pelanggan tersebut akan kembali kepada perusahaan untuk mencari barang/jasa.

2. Menciptakan Word-of-Mouth: Dalam hal ini, pelanggan akan mengatakan hal-hal yang baik tentang perusahaan kepada orang lain.

3. Menciptakan Citra Merk: Pelanggan akan kurang memperhatikan merk dan iklan dari produk pesaing.

4. Menciptakan keputusan pembelian pada perusahaan yang sama: membeli produk lain dari perusahaan yang sama.

\section{Pengaruh Kualitas Pelayanan Terhadap Kepuasan Pelanggan \\ Kualitas pelayanan yang diberikan} suatu klinik dapat meningkatkan kepuasan pasien karena peningkatan kualitas pelayanan dapat meningkatkan kepuasan dan mengembangkan sikap loyal seseorang yang pada akhirnya dapat memepertahankan pasien tersebut untuk terus menggunakan klinik tersebut (Setiawan, 2016). Apabila seseorang pasian merasa bahwa klinik Isna Medika Kota Cilegon memberikan pelayanan dengan baik selama mereka mengunjungi kllinik tersebut, orang tersebut akan merasa puas terhadap klinik tersebut karena mereka merasa dilayani dengan baik, tidak mengalami hal buruk dan biaya yang dikeluarkan sesuai dengan layanan yang mereka dapatkan. Karena semakin tinggi kualitas pelayanan yang dirasakan pelanggan maka akan meningkatkan kepuasan pasien, sebaliknya ketika kualitas pelayanan yang diberikan suatu klinik kepada pasien dirasa berkurang dari harapan pasien maka pasien akan merasa dan menunjukkan sikap tidak puas. Hal ini didukung oleh beberapa penelitian terdahulu yang menemukan bahwa kualitas pelayanan berpengaruh positif terhadap kepuasan pelanggan (Setiawan, 2016; Santi dan Huda, 2015). Berdasarkan penjelasan tersebut, maka peneliti merumuskan hipotesis sebagai berikut:

\section{Pengaruh Kepercayaan Terhadap Kepuasan Pelanggan}

Karena kepercayaan pelanggan yang kuat akan memungkinkan pelanggan untuk yakin bahwa klinik Isna Medika Kota Cilegon merupakan penyedia layanan kesehatan yang baik (Setiawan, 2016). Kepercayaan tersebut akan mempengaruhi persepsi pasien dari keselarasan nilai dengan penyedia layanan kesehatan. Artinya, jika seorang pasien merasa bahwa klinik tersebut dapat dipercaya dalam memberikan pelayanan kesehatan karena klinik tersebut memiliki keahlian, integritas, kejujuran dan kebaikan hati dalam melayani pasien, pasien tersebut akan merasa puas karena pilihan mereka tidak salah. Hal ini didukung oleh beberapa penelitian terdahulu yang menemukan bahwa kebermanfaatan persepsian berpengaruh positif terhadap niat menggunakan (Setiawan, 2016; Rosannah, 2014). Berdasarkan penjelasan tersebut, maka peneliti merumuskan hipotesis sebagai berikut:

\section{Hipotesis Penelitian}

Berdasarkan penjelasan tersebut, maka peneliti merumuskan hipotesis sebagai berikut:

H1: Kualitas pelayanan berpengaruh 
positif terhadap kepuasan pasien BPJS

$\mathrm{H} 2$ : Kepercayaan berpengaruh positif terhadap kepuasan pasien BPJS

H3: Kualitas pelayanan dan kepercayaan berpengaruh secara bersama-sama (simultan) terhadap kepuasan pasien BPJS

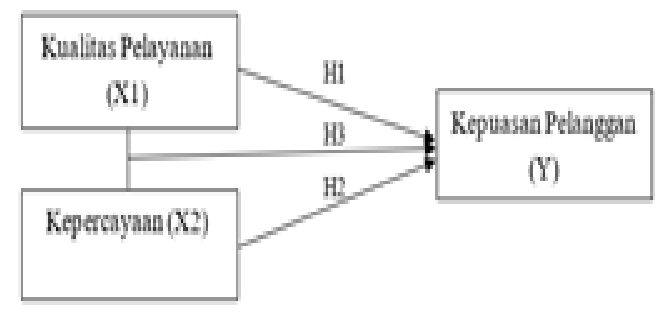

Gambar 1. Kerangka Pemikiran

\section{METODE PENELITIAN}

Penelitian ini dilakukan dengan menggunakan pendekatan kuantitatif yang memandang bahwa perilaku atau tingkah laku manusia dapat diramalkan, objektif dan dapat diukur (Yusuf, 2017). Populasi dalam penelitian ini adalah seluruh pasien BPJS Klinik Isna Medika Cilegon. Hair et al., (2010) merekomendasikan jumlah sampel minimal adalah 5 kali dari jumlah item pertanyaan yang terdapat di kuisioner. Penelitian ini menggunakan 24 pernyataan, sehingga minimal sampel penelitian ini adalah 120 responden. Pengumpulan data dalam penelitian ini dilakukan dengan menggunakan metode survei, dimana penelitian melakukan penyebaran kuesioner kepada responden secara langsung yaitu pasien pengguna BPJS kesehatan di Klinik Isna Medika Kota Cilegon. Metode ini merupakan teknik pengumpulan data yang tepat dimana peneliti bisa memastikan bahwa responden yang mengisi kuesioner adalah benar-benar pasien pengguna BPJS kesehatan di Klinik Isna Medika Kota Cilegon. Selanjutnya, peneliti menggunakan analisis regresi linier berganda untuk melakukan analisis data dengan menggunakan program SPSS versi 23.

\section{HASIL PENELITIAN \\ Uji Validitas}

Uji validitas digunakan untuk mengukur valid atau tidaknya suatu kuesioner. Suatu kuesioner dikatakan valid jika pertanyaan pada kuesioner tersebut mampu mengukur variabel yang ingin diukur (Ghozali, 2018). Itemitem penyataaan dikatakan valid jika $r$ hitung $>r_{\text {tabel, }}$ sebaliknya jika $r_{\text {hitung }} \leq r_{\text {tabel }}$ maka peryatan dinyatakan tidak valid. Penelitian ini menggunakan sampel sebanyak 120 responden dengan tingkat probabilitas $5 \%$, sehingga didapati nilai $\mathrm{r}_{\text {tabel }}$ sebesar 0,179. Lebih lengkap hasil pengujian validitas dapat di lihat pada Tabel di bawah ini.

\section{Tabel 2. Hasil Uji Validitas}

\begin{tabular}{ccccc}
\hline Variabel & No & $\begin{array}{c}\text { R } \\
\text { Hitung }\end{array}$ & R Tabel & $\begin{array}{c}\text { Ket- } \\
\text { erangan }\end{array}$ \\
\hline \multirow{6}{*}{ Kualitas } & KUP4 & 0,754 & & Valid \\
Pe- & KUP5 & 0,659 & 0,179 & Valid \\
layanan & KUP6 & 0,750 & & Valid \\
& KUP7 & 0,574 & & Valid \\
& KUP8 & 0,575 & & Valid \\
& KUP9 & 0,801 & & Valid \\
& & & & Valid \\
& KP10 & 0,359 & & Valid
\end{tabular}




\begin{tabular}{ccccc}
\hline & KEP1 & 0,843 & & Valid \\
& KEP2 & 0,839 & & Valid \\
Keper- & KEP3 & 0,774 & \multirow{2}{*}{0,179} & Valid \\
cayaan & KEP4 & 0,850 & & Valid \\
& KEP5 & 0,816 & & Valid \\
& KEP6 & 0,838 & & Valid \\
& KP1 & 0,795 & & Valid \\
& KP2 & 0,825 & & Valid \\
Kepua- & KP3 & 0,852 & & Valid \\
san & KP4 & 0,860 & \multirow{2}{*}{0,179} & Valid \\
Pelang- & KP5 & 0,770 & & Valid \\
gan & KP6 & 0,743 & & Valid \\
& KP7 & 0,845 & & Valid \\
& KP8 & 0,688 & & Valid \\
\hline
\end{tabular}

Berdasarkan uji validitas dengan menggunakan nilai $r_{\text {hitung }}$ dan nilai $r_{\text {tabel }}$ diatas terlihat semua item pengukuran memiliki nilai $\mathrm{r}_{\text {hitung }}$ yang lebih besar dari 0,179. Oleh karena itu, dapat disimpulkan bahwa secara keseluruhan item-item pengukuran tersebut dikatakan valid.

\section{Uji Reliabilitas}

Uji reliabilitas dilakukan dengna menggunakan membandingkan nilai cronbach alpha dengan nilai koefisiennya lebih besar atau sama dengan 0,6 (Ghozali (2018). Jika nilai koefisien Cronbach Alpha $>0,6$ maka pertanyaan dinyatakan reliabel. Sebaliknya, jika koefisien Cronbach Alpha $\leq$ 0,6 maka pertanyaan dinyatakan tidak reliabel. Hasil pengujian reliabilitas dapat dilihat pada Tabel 3.

\section{Tabel 3. Hasil Uji Reliabilitas}

\begin{tabular}{|c|c|c|c|c|}
\hline No & Variabel & Item & $\begin{array}{l}\text { Cron- } \\
\text { bach } \\
\text { Alpha }\end{array}$ & Hasil \\
\hline 1 & $\begin{array}{l}\text { Kualitas pe- } \\
\text { layanan }\end{array}$ & 10 & 0,827 & Reliabel \\
\hline 2 & Kepercayaan & 6 & 0,905 & Reliabel \\
\hline 3 & $\begin{array}{l}\text { Kepuasan } \\
\text { pelanggan }\end{array}$ & 8 & 0,916 & Reliabel \\
\hline
\end{tabular}

Hasil uji reliabilitas pada tabel di atas, menunjukkan bahwa secara keseluruhan variabel memiliki nilai cronbach alpha diatas 0,6. Berdasarkan pengujian instrumen ini dapat disimpulkan bahwa semua item tidak memiliki masalah validitas dan reliabilitas.

\section{Uji Asumsi Klasik Uji Normalitas}

Uji normalitas bertujuan untuk menguji apakah sampel yang digunakan mempunyai distribusi normal atau tidak. Uji normalitas bertujuan untuk mengetahui apakah varibel-variabel penelitian memiliki distribusi normal atau tidak. Peneliti menggunakan analisa histogram regression residual dan P-P plot sebagai berikut:

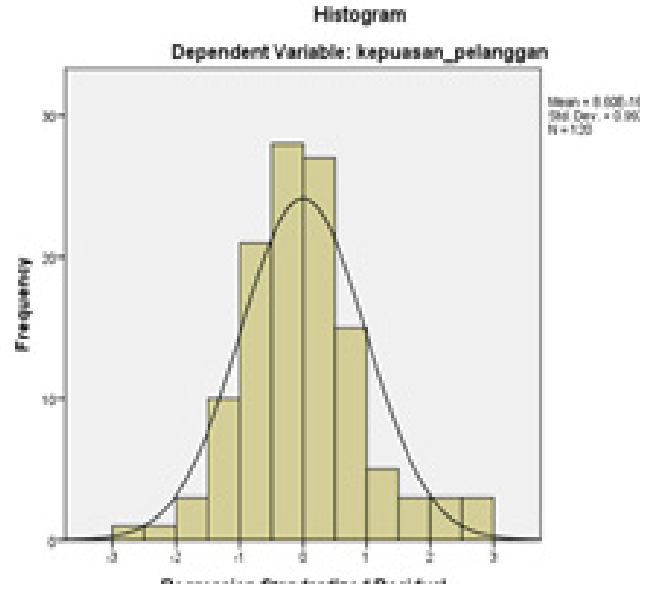

\section{Gambar 2. Histogram Regression Residual}

Dari Gambar 2 terlihat bahwa nilai residual berbentuk lonceng (bell-shaped curve) yang kedua sisinya melebar sampai tidak terhingga. Selanjutnya, uji normalitas juga dilakukan dengan melihat probability plot dibawah ini. 


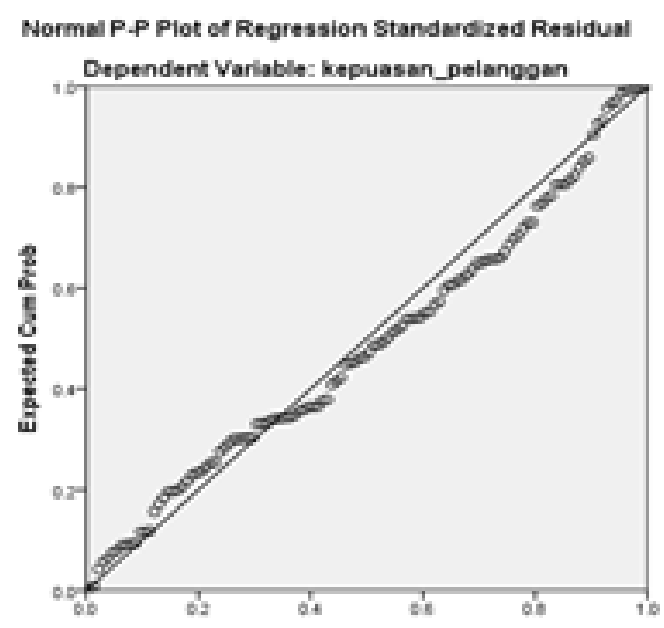

Gambar 3. P-plot Regression
Dari Gambar 3 dapat di lihat gambar distribusi dengan titik-titik data yang menyebar disekitar garis diagonal dan penyebaran titik-titik data searah mengikuti garis diagonal maka variabel berdistribusi normal. Berdasarkan Gambar 2 dan Gambar 3 diatas, dapat disimpulkan bahwa Histogram Regression Residual dan P-Plots menunjukkan pola data distribusi normal.

Peneliti menggunakan uji statistik untuk melakukan pengujian normalitas data yaitu dengan menggunakan uji Kolmogorov-Smirnov (K-S) dalam program SPSS. Hasil uji KolmogorovSmirnov terlihat pada tabel di bawah ini.

Tabel 3. Hasil Uji Kolmogorov-Smirnov

\begin{tabular}{|c|c|c|}
\hline & & $\begin{array}{l}\text { Unstandardiz } \\
\text { ed Residual }\end{array}$ \\
\hline $\mathrm{N}$ & & 120 \\
\hline \multirow[t]{2}{*}{ Normal Parameters ${ }^{a b}$} & Mean & 0000000 \\
\hline & Std. Deviation & 3.97058755 \\
\hline \multirow[t]{3}{*}{ Most Extreme Differences } & Absolute & .080 \\
\hline & Positive & .080 \\
\hline & Negative & -.053 \\
\hline Test Statistic & & .080 \\
\hline Asymp. Sig. (2-tailed) & & $.055^{\circ}$ \\
\hline
\end{tabular}

a. Test distribution is Normal.

Dari Tabel 3 menunjukkan nilai Kolmogorov-Smirnov Z sebesar 0,080 dengan nilai signifikansi sebesar 0,055 lebih besar dari 0,05 maka dapat disimpulkan bahwa data yang digunakan dalam penelitian ini data distribusi normal. Oleh karena itu, dapat disimpulkan bahwa data dalam penelitian ini memenuhi kriteria uji normalitas.

Uji Multikolinearitas

Uji multikolinearitas dilakukan untuk mendeteksi ada tidaknya korelasi antar variabel independen. Uji multikolinearitas dapat dilihat dari nilai tolerance dan variance inflation factor (VIF). Pada Tabel 4 dapat dilihat hasil pengujian multikolinearitas.

Tabel 4. Hasil Uji Multikolinearitas

\begin{tabular}{lcc}
\hline \multicolumn{1}{c}{ Model } & \multicolumn{2}{c}{ Collinearity Statistics } \\
& Tolerance & VIF \\
\hline (Constant) & & \\
Kualitas_Pelayanan & .643 & 1.555 \\
Kepercayaan & .643 & 1.555 \\
\hline
\end{tabular}

Berdasarkan tabel diatas, dapat 
diketahui bahwa semua variabel independen, yaitu kualitas pelayanan (X1) dan kepercayaan (X2) memiliki nilai tolerance lebih besar dari 0,10 dan nilai VIF lebih kecil dari 10. Artinya, tidak terdapat multikolinearitas, sehingga data baik digunakan dalam model regresi. Kriteria yang dipakai untuk menunjukkan ada tidaknya gejala multikolinearitas yaitu tolerance value $>0,10$ atau sama dengan $\mathrm{VIF}<10$.

\section{Uji Autokorelasi}

Uji autokorelasi bertujuan menguji apakah dalam model regresi linear ada korelasi antara kesalahan pengganggu pada periode $\mathrm{t}$ dengan kesalahan pengganggu pada periode t-1 (sebelumnya). Uji yang digunakan untuk mendeteksi adanya autokorelasi yaitu Uji Durbin-Watson (DW). Hasil uji durbin-watson dapat di lihat pada tabel di bawah ini.

\section{Tabel 5. Hasil Uji Autokorelasi}

\begin{tabular}{|l|r|r|r|r|r|}
\hline Model & $R$ & R Square & \multicolumn{1}{|c|}{$\begin{array}{c}\text { Adjusted R } \\
\text { Square }\end{array}$} & $\begin{array}{c}\text { Std. Error of } \\
\text { the Estimate }\end{array}$ & \multicolumn{1}{c|}{$\begin{array}{c}\text { Durbin- } \\
\text { Watson }\end{array}$} \\
\hline 1 & $.597^{\mathrm{a}}$ & .357 & .346 & 4.00438 & 1.775 \\
\hline
\end{tabular}

a. Predictors: (Constant), kepercayaan, Kualitas_Pelayanan

b. DependentVariable: kepuasan_pelanggan

Dari tabel 5 di atas, diperoleh nilai Durbin-Watson test sebesar 1,775. Hal ini berarti nilai DW berada di antara du (1,73608) sampai dengan 4-du $=2,2639$. Dengan demikian sampel observasi 120 dan 3 variabel penjelas, nilai kritis Durbin-Watson pada tingkat signifikan $95 \%(\alpha=0,05)$. Nilai DurbinWatson 1,775 berada pada daerah tidak ada autokorelasi positif atau negatif.

\section{Analisis Regresi Berganda}

Analisis ini digunakan untuk mengetahui seberapa besar pengaruh variabel dukungan sosial (X1) dan kepuasan kerja (X2) terhadap variabel kinerja karyawan (Y). Hasil uji linier berganda dalam penelitian ini dapat dilihat dalam tabel dibawah ini:

Tabel 6. Hasil Uji Regres Linier Berganda

\begin{tabular}{|c|c|c|c|c|c|c|}
\hline \multirow[b]{2}{*}{ Model } & & \multicolumn{2}{|c|}{ Unstandardized Coefficients } & \multirow{2}{*}{\begin{tabular}{|c|}
$\begin{array}{c}\text { Standardized } \\
\text { Coefficients }\end{array}$ \\
Beta \\
\end{tabular}} & \multirow[b]{2}{*}{1} & \multirow[b]{2}{*}{ Sig. } \\
\hline & & 8 & Std. Error & & & \\
\hline \multirow[t]{3}{*}{1} & (Constant) & 7.136 & 3.158 & & 2.259 & .026 \\
\hline & Kualitas_Pelayanan & .504 & .098 & .476 & 5.148 & .000 \\
\hline & kepercayaan & .215 & .114 & .175 & 1.889 & .061 \\
\hline
\end{tabular}

a. DependentVariable: Kepuasan_pelanggan

Berdasarkan hasil dari koefisien diatas dapat dikembangkan dengan model persamaan regresi linier berganda sebagai berikut

Kepuasan pelanggan $(\mathrm{Y})=7,136+$ $0,504 \mathrm{X} 1+0,215 \mathrm{X} 2+\mathrm{e}$

Dari persamaan regresi yang telah disusun diatas, dapat diinterpretasikan sebagai berikut:

1. Nilai konstanta sebesar 7,136 menunjukkan bahwa apabila variabel independen bernilai nol (0) atau ditiadakan, maka kepuasan pelanggan adalah sebesar 7,136.

2. Koefisien kualitas pelayanan sebesar 0,504 menunjukkan bahwa setiap penambahan kualitas pelayanan sebesar satu satuan, maka akan diikuti oleh kenaikan kepuasan pelanggan sebesar 0,504.

3. Koefisien kepercayaan sebesar 0,215 menunjukkan bahwa setiap penambahan kepercayaan sebesar satu satuan, maka akan diikuti 
oleh kenaikan kepuasan pelanggan sebesar 0,215 .

\section{Koefisien Determinasi (R2)}

Menurut Ghozali

pengujian koefisien determinasi $\left(\mathrm{R}^{2}\right)$ dilakukan untuk mengetahui seberapa besar kemampuan variabel bebas dalam menerangkan variabel terikat. Nilai determinasi ditentukan dengan nilai Adjusted $R$ Square. Nilai koefisien ini antara 0 dan 1, jika hasil lebih mendekati angka 0 berarti kemampuan variabel-variabel amat terbatas. Tetapi jika hasil mendekati angka 1 berarti variabel-variabel independen memberikan hampir semua informasi yang dibutuhkan untuk memprediksi variasi variabel dependen.

Tabel 7. Hasil Analisis Koefisien Determinasi

\begin{tabular}{|l|c|r|r|r|}
\hline Model & $R$ & R Square & $\begin{array}{c}\text { Adjusted R } \\
\text { Square }\end{array}$ & $\begin{array}{l}\text { Std. Error of } \\
\text { the Estimate }\end{array}$ \\
\hline 1 & $.597^{\mathrm{a}}$ & .357 & .346 & 4.00438 \\
\hline
\end{tabular}

a. Predictors: (Constant), kepercayaan, Kualitas_Pelayanan

b. Dependent Variable: kepuasan_pelanggan

Tabel 7 menunjukkan bahwa nilai Adjusted $\mathrm{R}^{2}$ mencerminkan kemampuan variabel bebas menjelaskan variasi variabel terikat. Berdasarkan pengolahan menggunakan software windows SPSS 23 didapatkan nilai Adjusted $\mathrm{R}^{2}$ adalah $34,6 \%$. Nilai ini menunjukkan bahwa $34,6 \%$ dari variasi nilai variabel kepuasan pelanggan yang dapat dijelaskan oleh kualitas pelayanan dan kepercayaan, sedangkan sisanya sebesar $65,4 \%$ dijelaskan oleh variabelvariabel lain yang tidak termasuk dalam penelitian ini

\section{Pengujian Hipotesis \\ Uji t}

Uji t digunakan untuk mengetahui ada tidaknya pengaruh secara linier antara variabel bebas dan variabel terikat. Uji t dilakukan dengan membandingkan nilai $t$ hitung dengan $\mathrm{t}$ tabel. Hasil uji $\mathrm{t}$ dapat dilihat dalam Tabel 8.

Tabel 8. Hasil Uji t

\begin{tabular}{ccccccc}
\hline$N_{0}$ & Variabel & T hitung & T tabel & Sig & A & keterangan \\
\hline \multirow{2}{*}{1} & Kualitas & S,148 & & 0,000 & & Berpengaruh \\
& pelayanan & & 1,980 & & 0,05 & $\begin{array}{c}\text { Tidak } \\
2\end{array}$ \\
2 & Kepercayaan & 1,889 & & 0,061 & & Berpengaruh \\
\hline
\end{tabular}

Tabel 8 menunjukkan bahwa variabel kualitas pelayanan diperoleh nilai $t_{\text {hitung }}$ yang lebih besar dari $t_{\text {tabel }}$ yaitu 5,148 $>1,980$ dan nilai signifikansinya lebih kecil dari tingkat probabilitasnya yaitu $0,000<0,05$, maka Ho ditolak dan $\mathrm{Ha}$ diterima. Artinya bahwa variabel kualitas pelayanan berpengaruh positif dan signifikan terhadap kepuasan pelanggan. Dari hasil uji t juga dapat disimpulkan bahwa pada variabel kepercayaan diperoleh nilai $\mathrm{t}_{\text {hitung }}$ yang lebih kecil dari $t_{\text {tabel }}$ yaitu $1,889<1,980$ dan nilai signifikansinya lebih besar dari tingkat probabilitasnya yaitu $0,061>$ 0,05, maka Ha ditolak dan Ho diterima. Artinya bahwa variabel kepercayaan tidak memiliki pengaruh positif dan signifikan terhadap kepuasan pelanggan.

\section{Uji F}

Uji $F$ merupakan pengujian pengaruh secara simultan yang digunakan untuk mengetahui apakah variabel independen secara simultan mempengaruhi variabel independen (Ghozali, 2018). Hasil uji F dapat dilihat 
dalam tabel di bawah ini:

Tabel 9. Hasil Uji F

\begin{tabular}{|c|c|c|c|c|c|c|}
\hline Mode & & $\begin{array}{c}\text { Sum of } \\
\text { Squares }\end{array}$ & $\mathrm{df}$ & Mean Square & $\mathrm{F}$ & Sig. \\
\hline \multirow[t]{3}{*}{1} & Regression & 1039.864 & 2 & \multirow{3}{*}{$\begin{array}{r}519.932 \\
16.035\end{array}$} & \multirow[t]{3}{*}{32.425} & \multirow[t]{3}{*}{$.000^{\mathrm{b}}$} \\
\hline & Residual & 1876.102 & 117 & & & \\
\hline & Total & 2915.967 & 119 & & & \\
\hline
\end{tabular}

Hasil uji F pada Tabel 9 menunjukkan bahwa nilai $\mathrm{F}_{\text {hitung }}$ lebih besar dari pada nilai $\mathrm{F}$ tabel $(32,425>3,07)$, artinya kedua variabel independen dalam penelitian ini secara bersama-sama mempengaruhi variabel dependen dengan nilai signifikansi lebih kecil dari nilai probabilitas $(0,000<0,05)$. Dengan begitu, dapat dikatakan bahwa kualitas pelayanan dan kepercayaan berpengaruh secara simultan terhadap kepuasan pelanggan.

\section{PEMBAHASAN}

\section{Pengaruh Kualitas Pelayanan Terhadap Kepuasan Pelanggan}

Hipotesis pertama adalah untuk mengetahui apakah ada pengaruh kualitas pelayanan terhadap kepuasan pelanggan. Hasil penelitian menunjukkan bahwa variabel kualitas pelayanan diperoleh nilai $t_{\text {hitung }}$ sebesar 5,148 dan nilai $t_{\text {tabel }}$ sebesar 1,980 dan nilai signifikansi sebesar 0,000 . Hasil ini menunjukkan bahwa nilai $\mathrm{t}$ hitung lebih besar dari pada nilai $\mathrm{t}_{\text {tabel }}(5,148$ $>1,980$ ) dan nilai signifikansinya lebih kecil dari nilai $\alpha=0,05(0,000>0,05)$, dan koefisien regresi memiliki nilai 0,504 . Artinya penelitian ini berhasil membuktikan hipotesis pertama yang menyatakan bahwa kualitas pelayanan memiliki pengaruh positif dan signifikan terhadap kepuasan pelanggan.

Hasil penelitian ini sejalan dengan penelitian yang dilakukan oleh Setiawan (2016) dan Santi dan Huda (2015) yang menemukan bahwa kepuasan pasien ditentukan oleh kualitas pelayan yang diberikan oleh penyedia layanan kesehatan. Penelitian ini menemukan bahwa Klinik Isna Medika di Kota Cilegon telah memberikan layanan kesehatan yang berkualitas bagi para pasiennya sehingga merasa merasa puas dan akan menggunakan kembali layanan tersebut di kemudian hari.

\section{Pengaruh Kepercayaan Terhadap Kepausan Pelanggan}

Hipotesis kedua adalah untuk mengetahui apakah ada pengaruh kepercayaan terhadap kepuasan pelanggan. Hasil penelitian menunjukkan bahwa variabel kepercayaan diperoleh nilai $t_{\text {hitung }}$ sebesar 1,889 dan nilai $t_{\text {tabel }}$ sebesar 1,980 dan nilai signifikansi sebesar 0,061 . Hasil ini menunjukkan bahwa nilai $t$ hitung lebih besar dari pada nilai $\mathrm{t}_{\text {tabel }}(1,889$ $<1,980)$ dan nilai signifikansinya lebih kecil dari nilai $\alpha=0,05(0,061>0,05)$, dan koefisien regresi memiliki nilai positif 0,215 . Artinya penelitian ini tidak berhasil membuktikan hipotesis kedua yang menyatakan bahwa kepercayaan memiliki pengaruh positif dan signifikan terhadap kepuasan pelanggan.

Hasil penelitian ini sejalan dengan penelitian yang dilakukan Santi dan Huda (2015) yang menemukan bahwa kepercayaan bukan merupakan faktor yang dapat mempengaruhi kepuasan pasien BPJS dalam menggunakan 
layanan kesehatan yang diberikan oleh penyedia layanan kesehatan. Penelitian ini menemukan bahwa pasien pengguna BPJS di klinik Isna Medika di Kota Cilegon belum yakin sepenuhnya bahwa klinik tersebut memiliki keahlian, integritas dan kebaikan hati yang tinggi serta mampu menyedikan layanan kesehatan yang baik bagi pasien penggunan BPJS.

\section{SIMPULAN DAN SARAN}

\section{Simpulan}

1. Kualitas pelayanan memiliki pengaruh positif dan signifikan terhadap kepuasan pasien BPJS pada Klinik Isna Medika di Kota Cilegon. Artinya, klinik telah menyediakan layanan yang berkualitas dan dirasakan oleh pasien manfaatnya sehingga mampu memunculkan kepuasan bagi pasien tersebu.

2. Kepercayaan pasien tidak memiliki pengaruh yang signifikan terhadap kepuasan pasien BPJS pada Klinik Isna Medika di Kota Cilegon. Artinya, pasien sebagai pelanggan belum yakin sepenuhnya bahwa klinik tersebut memiliki keahlian, integritas dan kebaikan hati dalam melayani pasien dengan baik sehingga membuat mereka belum merasa puas terhadap layanan yang diberikan

3. Kualitas pelayanan dan kepercayaan pasien memiliki pengaruh secara simultan terhadap kepuasan pasien BPJS pada Klinik Isna Medika di Kota Cilegon.

\section{Saran}

1. Hasilpenelitianinidiharapkanmampu membuat perusahaan khususnya Klinik Isna Medika di Kota Cilegon untuk berupaya terus meningkatkan kualitas pelayanan karena pasien khususnya pengguna BPJS kesehatan sangat mengutamakan kualitas pelayanan untuk bisa merasa puas terhadap suatu produk atau jasa atau perusahaan. Selain itu, pihak klinik juga perlu meningkatkan integritas, kejujuran dan kebaikan hati dalam melayani pasien pengguna BJPS kesehatan agar dapat menumbuhkan kepercayaan mereka terhadap klinik sebagai penyedia layanan kesehatan

2. Bagi peneliti selanjutnya diharapkan dapat menambah faktor lain seperti citra dokter dan kemampuan dokter yang memberikan layanan kesehatan bagi pengguna BPJS kesehatan. Selain itu, penelitian selanjutnya juga dapat menambahkan faktor lain yang berasal dari individu tersebut sebagai faktor penentu kepuasan pasien seperti ekspektasi pasien dan pengalaman pasien. Penelitian selanjutnya juga bisa dilakukan pada rumah sakit pemerintah atau rumah sakit swasta agar dapat memperbanyak jumlah sampel dan mendapatkan hasil yang lebih objektif serta dapat digeneralisasi.

\section{DAFTAR PUSTAKA}

Burhanuddin, Nufardiansyah. 2018. "Pengaruh Kualitas Pelayanan terhadap Kepuasan dan Kepercayaan pasien di Puskesmas Paccerakkang Makassar". Jurnal. Vol.3. No (1). 
Pratiwi, D.M. 2016. "Pengaruh Kualitas Pelayanan dan Kepercayaan terhadap Loyalitas Pelanggan pada perusahaan Otobus Akas IV Probolinggo". Jurnal. Vol.3. No (2).

Ghozali, I. 2018. Aplikasi Analisis Multivariate Dengan Program IBM Spss 25. Semarang: Badan Penerbit Universitas Diponegoro. Hair, J.F., William, B., Barry, J.B., dan Rolph, A. 2010. Multivariate Data Analysis (7th ed). USA: Pearson Presntice Hall.

Jitas, Thomas. 2017. "Pengaruh Kualitas Pelayanan dan Kepercayaan Konsumen terhadap Keputusan Pembelian". Skripsi. (2017).

Kotler, P., dan Keller, K.L. 2012. Manajemen Pemasaran. Edisi 12. Jakarta: Erlangga.

Rosannah, F.S. 2014. Pengaruh kepercayaan dan kepuasan terhadap merek pada niat membeli ulang. Journal Siasat Bisnis, Vol 18. No 1, 63-80.

Santi, P., dan Huda, N. 2015. Analisis Kualitas Pelayanan, Kepercayaan dan Nilai Terhadap Kepuasan Peserta Didik Pada Lembaga Pendidikan dan Keterampilan (LPK) di Banjarmasin. Jurnal Wawasan Manajemen, vol 3. no 2, 183-199.

Setiawan, H. 2016. Pengaruh Kualitas Layanan, Persepsi Nilai Dan Kepercayaan Terhadap Kepuasan Dan Loyalitas Pengguna Layanan Mobile Banking. Jurnal Keuangan dan Perbankan, Vol 20, no.3, 518528.

Sugiyono. 2015. Metode Penelitian
Kuantitatif, Kualitatif dan R\&D. Bandung: Penerbit Alfabeta. Suwardi.(2011). Menujur Kepuasan Pelanggan melalui Penciptakaan Kualitas Pelayanan dalam Jurnal Ragam Jurnal Pengembangan Humaniora Vol. 11 No 1.

Tanudjaya, P.K. 2014. Pengaruh kualitas pelayanan klinik gigi terhadap kepuasan dan kepercayaan pasien sehingga menigkatkan keinginan untuk berobat kembali. Jurnal Manajemen Dan Pemasaran Jasa,. vol 7. no 1, 39-60.

Tjiptono, F dan Chandra, G. 2012. Pemasaran Strategik, Yogyakarta, Andi.

Wijayanti, Ari. (2008). Strategi Meningkatkan Loyalitas Melalui Kepuasan Pelanggan Pada Produk Kartu Seluler PraBayar Mentari- Indosat Wilayah Semarang. Program Studi Magister Manajemen. Universitas Diponegoro, Semarang.

Yusuf, M. 2017. Metode penelitian: kuantitatif, kualitatif dan penelitian gabungan, edisi pertama. Jakarta: Kencana. 